\title{
ERRATUM
}

Leonardo Resta $\cdot$ Domenico Piscitelli

Maria Grazia Fiore • Vincenzo Di Nicola

Maria Luisa Fiorella $\cdot$ Anna Altavilla $\cdot$ Andrea Marzullo

\section{Incidental metastases of well-differentiated thyroid carcinoma in lymph nodes of patients with squamous cell head and neck cancer: eight cases with a review of the literature}

Published online: 4 May 2006

(C) Springer-Verlag 2006

Eur Arch Otorhinolaryngol (2004) 261:473-478

The Christian names of the fifth author were not given correctly. The correct name is Maria Luisa Fiorella.

The online version of the original article can be found at http:// dx.doi.org/10.1007/s00405-003-0722-8

L. Resta $(\bowtie) \cdot$ D. Piscitelli · M. G. Fiore · A. Altavilla A. Marzullo

Department of Pathological Anatomy and Genetics, University of Bari Policlinico, Piazza Giulio Cesare 11, 70124 Bari, Italy

E-mail: 1resta@anatopat.uniba.it

Tel.: + 39-080-5478274

Fax: + 39-080-5478280

V. Di Nicola $\cdot$ M. L. Fiorella

Department of Ophtalmology and Otorhinolaryngology, University of Bari, Bari, Italy 